\title{
UNILATERAL ARYTENOIDECTOMY FOR INTRACTABLE ASPIRATION FOLLOWING SUPRACRICOID LARYNGECTOMY: A CASE OF SURGICAL DILEMMA
}

\author{
BIR CERRAHI ÇELIŞKI: SUPRAKRIKOID LARENJEKTOMI SONRASI TEDAVIYE DIRENÇLI \\ ASPIRASYONUN TEDAVISINDE TEK TARAFLI ARITENOIDEKTOMI
}

\author{
Mehmet ÇELIK (D), Can DORUK (D), Bora BAŞARAN (D) \\ Istanbul University, Istanbul Faculty of Medicine, Department of Otolaryngology \& Head and Neck Surgery, Istanbul, Turkey
}

Cite this article as: Çelik M, Doruk C, Başaran B. Unilateral arytenoidectomy for intractable aspiration following supracricoid laryngectomy: a case of surgical dilemma. J Ist Faculty Med 2018; 81(3): 99-101

\begin{abstract}
Supracricoid partial laryngectomy (SCPL) is a procedure in which the functions of the larynx are preserved. Swallowing difficulties is the most common functional impairment following SCPL. It has been suggested that sparing the arytenoid cartilages is beneficial for the rapid recovery of the swallowing function after SCPL. In this case report we present a 67-year-old male who underwent SCPL in 2015, in which both arytenoid cartilages were preserved. Following the procedure, the patient had severe aspiration and swallowing problems. In order to save the patient from total laryngectomy a one sided arytenoidectomy was performed successfully. The patient no longer required his gastrostomy tube afer 3 months.
\end{abstract}

Keywords: Supracricoid laryngectomy, swallowing problems, arytenoidectomy

\section{ÖZET}

Suprakrikoid larenjektomi larenks fonksiyonlarının korunduğu parsiyel larenjektomi metodlarından biridir. Bu operasyonları takiben en sık görülen fonksiyonel bozukluk yutma güçlüğüdür. Aritenoid kartilajların bilateral korunmasının postoperatif dönemde yutma fonksiyonlarının çabuk iyileşmesinde faydalı olduğu bildirilmektedir. Bu olgu sunumumuzda 2015 yılında her iki aritenoid kartilajın korunduğu suprakrikoid larenjektomi yapılmış bir erkek hastayı sunmaktayız. Hastanın postoperatif dönemde şiddetli aspirasyon ve yutma problemleri olmuştur. Hastayı total larenjektomiden kurtarmak için tek taraflı aritenoidektomi denenlmiş ve başarılı olmuştur. Hasta postoperatif 3. ay takibinde gastrostomi tübünden kurtulmuştur.

Anahtar Kelimeler: Suprakrikoid larenjektomi, yutma problemi, aritenoidektomi

\section{INTRODUCTION}

Supracricoid partial laryngectomy (SCPL), which is a horizontal partial laryngectomy procedure for laryngeal cancer, is based on preserving the respiratory, sphincter and phonation functions of the larynx. SCPL is a surgical procedure in which the thyroid cartilage and true and false vocal folds are resected while preserving at least one arytenoid cartilage. There are two types of SCPL. The first procedure in particular, is applied to glottic carcinomas where the preepiglottic space and epiglottis are spared, and reconstruction is done by suturing the cricoid cartilage to the epiglottis, hyoid bone, and tongue base: cricohyoidoepiglottopexy (CHEP). The second procedure is used for supraglottic and transglottic carcinomas, where the epiglottis and preepiglottic space are resected and reconstructed by suturing the cricoid cartilage to the hyoid and tongue base: cricohyoidopexy (CHP) (1).

Swallowing difficulties is the most common functional impairment following SCPLs. Several studies have reported that the overall incidence of temporary aspiration after SCPLs varies from $32 \%$ to $89 \%$. Thereby, recurrent or occasional episodes of aspiration after SCPL can lead to fatal diseases such as pneumonia (2).

It is suggested that sparing both of the arytenoid cartilages is beneficial for the rapid recovery of the swallowing func-

İletişim kurulacak yazar/Corresponding author: can.doruk@istanbul.edu.tr

Geliş tarihi/Received Date: 10.10.2017 • Kabul tarihi/Accepted Date: 07.05.2018

CCopyright 2018 by J Ist Faculty Med - Available online at jmed.istanbul.edu.tr

CTelif Hakkı $2018 \mathrm{~J}$ Ist Faculty Med - Makale metnine jmed.istanbul.edu.tr web sayfasından ulaşılabilir. 
tion after SCPL $(3,4)$. Conversely in our study, we presented a patient with constant aspiration following CHP who was treated with unilateral arytenoid resection.

\section{CASE PRESENTATION}

In this case report we present a 67-year-old male who underwent a supracrycoid partial laryngectomy (CHP) with bilateral functional neck dissection in 2015. Postoperative pathological analysis was squamous cell carcinoma with low differentiation, and the stage of the tumor was T2N0M0. The tumor originated from the petiole of the larynx and was invading the ventricules and anterior vocal cords bilaterally and extending to the anterior commissure with no cartilage invasion. The patient did not get any adjuvant therapy.

Oral feeding was attempted in the $3^{\text {rd }}$ week postoperatively. The patient could not tolerate any kind of oral intake, so a close monitoring period was started. After a 3 months follow-up with a nasogastic feeding tube no improvement was observed, and so an endoscopic percutaneous gastrostomy tube was inserted. In total the patient was monitored for 1 year with the g-tube; during this period although some improvement was observed (especially with a semi-solid and solid diet), the patient still could not tolerate any kind of oral liquid intake. Although the patient consented to a total laryngectomy to prevent aspiration, before carrying out a major and irreversible surgery our senior head and neck oncologist decided to perform a one sided arytenoidectomy which was a surgical dilemma for a patient with SCPL. The logic behind this idea was purely mechanical; arytenoid cartilages which were shifted medially due to the laryngectomy were contacting more medially than normal and thus preventing the neoglottis to close appropriately. In the first week follow up after surgery, the laryngoscopic examination showed full closure of the larynx, and no penetration was observed during functional endoscopic evaluation of swallowing (FEES). In the third month follow up the patient stated that he had no complaints during oral intake and he was not dependent on the g-tube (Figure1).
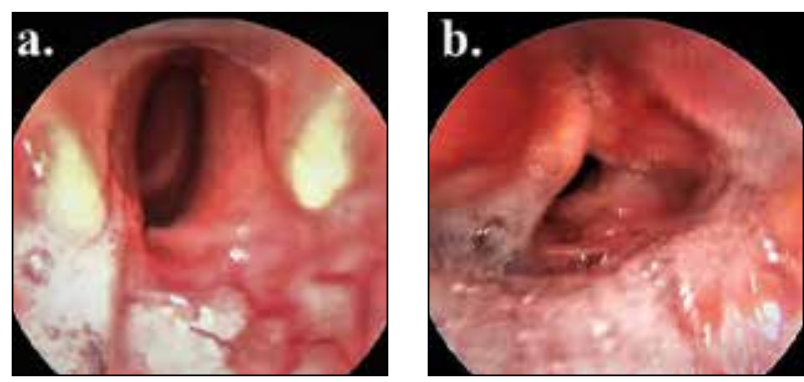

\section{DISCUSSION}

The main purpose of conservative laryngeal surgery for glottic carcinoma is to provide local control by maintaining laryngeal function. In recent reports, SCPL was shown to allow excellent local control rates ranging from 94 to $98.2 \%$ at 5 years in cases of T1-T2 glottic carcinoma with extension to the anterior commissure (5-8).

It is generally agreed that SCPL results in severe swallowing dysfunction, most notably aspiration, but eventual return to oral nutrition in most cases (9). However, episodes of

aspiration can occasionally occur throughout the patient's life. Furthermore, pulmonary diseases associated with aspiration that could be life threatening and require prompt diagnosis and treatment can occur.

Maintaining proper laryngopharyngeal sensation, re-creating a functional neoglottic valve and an adequate airway and enhancing physiological coordination during deglutition are crucial for successful rehabilitation of swallowing. In addition, posterior and lateral cricoarytenoid muscle preservation with normal recurrent laryngeal nerve function during SCPL can be beneficial for neoglottic functions postoperatively. Furthermore, total resection of one arytenoid cartilage, reconstruction with $\mathrm{CHP}$, and not repositioning the pyriform sinuses create a risk after SCPL (4).

Various studies have reported that sparing both arytenoid cartilages speeds recovery of swallowing after SCPL $(3,4,6,9)$. On the contrary, Bron et al. have argued that sparing of arytenoid cartilages has very little impact on the recovery of perfect swallowing. Moreover, they reported that one arytenoid resection may be necessary to recover perfect swallowing. This has been explained by the presence of a relatively wide laryngeal closure defect that causes chronic aspiration in cases where both arytenoids are preserved and most of the vocal cords need to be sacrificed. Additionally, they reported that resection of one arytenoid allows either the base of the tongue or suprahyoid epiglottis to form a tight laryngeal sphinc-
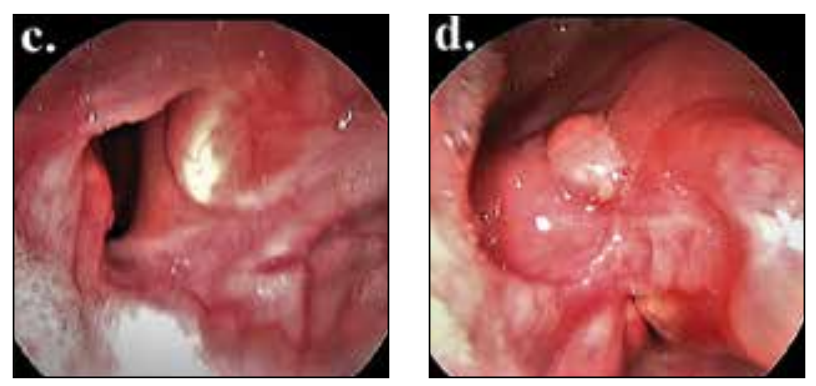

Figure 1. a-d. Neoglottic opening position at 1 year after $\mathrm{CHP}(\mathrm{a})$, closure position at the same time (b), neoglottic opening position at 3 months later after unilateral arytenoidectomy (c), closure position at the same time (d). 
ter with the remaining arytenoid cartilage (10). Similarly, in our case, despite the preservation of both arytenoid cartilages with normal recurrent laryngeal nerve function during $\mathrm{SCPL}$, chronic aspiration related to the laryngeal closure defect were observed postoperatively. This may be explained by the following situations: Firstly, most of each vocal cord had to be resected for local control. Secondly, both arytenoid cartilages were obstructing each other's medialization for neoglottic closure. As a result, unilateral arytenoid resection allowed complete medialization of the remaining arytenoid, which enables the sphincter function of the neoglottis.

\section{CONCLUSION}

Swallowing difficulties is a commonly observed complication after SCPL. Although it has been reported that preservation of both arytenoid cartilages facilitates the rehabilitation of swallowing postoperatively, we have resolved the swallowing problem by scarifying the unilateral arytenoid unit. Unilateral arytenoid resection may be considered for patients who have swallowing disorders after SCPL and where swallowing rehabilitation proves ineffective.

\section{SUMMARY}

Supracricoid partial laryngectomy is a commonly used surgical technique in which the functional properties of the lar$y n x$ are preserved. Swallowing difficulties is one of the most commonly seen complications of this procedure. It is known that sparing both of the arytenoid cartilages is important for swallowing recovery. In this case report we aimed to show that sparing the arytenoid cartilages can be the cause of aspiration, and a one sided arytenoidectomy should be considered before attempting any other surgical solutions.

Informed Consent: Written informed consent was obtained from patients who participated in this study.

Peer-review: Externally peer-reviewed.

Author Contributions: Concept-M.Ç, C.D, B.B.; Design - M.Ç, C.D, B.B.; Supervision - M.Ç, C.D, B.B.; Resources - C.D.; Materials - C.D.; Data Collection and/or Processing - M.Ç, C.D, B.B; Analysis and/or Interpretation - M.Ç, B.B.; Literature Search M.Ç, C.D; Writing Manuscript - M.Ç, C.D.; Critical Review - B.B.

Conflict of Interest: The authors have no conflict of interest to declare.

Financial Disclosure: The authors declared that this study has received no financial support.

Hasta Onamı: Yazılı hasta onamı bu çalışmaya katılan hastalardan alınmıştır.
Hakem Değerlendirmesi: Dış bağımsız.

Yazar Katkıları: Fikir - M.Ç., C.D., B.B.; Tasarım - M.Ç., C.D., B.B.; Denetleme - M.Ç., C.D., B.B.; Kaynaklar - C.D.; Malzemeler - C.D.; Veri Toplanması ve/veya İşlemesi - M.Ç., C.D., B.B.; Analiz ve/veya Yorum - M.Ç., B.B.; Literatür Taraması - M.Ç., C.D.; Yazıyı Yazan - M.Ç., C.D.; Eleştirel Inceleme - B.B.

Çıkar Çatışması: Yazarlar çıkar çatışması bildirmemişlerdir.

Finansal Destek: Yazarlar bu çalışma için finansal destek almadıklarını beyan etmişlerdir.

Hasta Onamı: Yazılı hasta onamı bu çalışmaya katılan

\section{REFERENCES}

1. Flint PW, Haughey BH, Robbins KT, Thomas JR, Niparko JK, Lund VJ, et al. Cummings otolaryngology-head and neck surgery: E Health Sci; 2014.

2. Makeieff M, Venegoni D, Mercante G, Crampette L, Guerrier B. Supracricoid partial laryngectomies after failure of radiation therapy. Laryngoscope 2005;115(2):353-7. [CrossRef]

3. Akbas Y, Demireller A. Oncologic and functional results of supracricoid partial laryngectomy with cricohyoidopexy. Otolaryngol Head Neck Surg 2005;132(5):783-7. [CrossRef]

4. Benito J, Holsinger FC, Pérez-Martín A, Garcia D, Weinstein GS, Laccourreye O. Aspiration after supracricoid partial laryngectomy: incidence, risk factors, management, and outcomes. Head Neck 2011;33(5):679-85. [CrossRef]

5. Chevalier D, Laccourreye $O$, Laccourreye $H$, Brasnu D, Piquet J-J. Cricohyoidoepiglottopexy for glottic carcinoma with fixation or impaired motion of the true vocal cord: 5-year oncologic results with 112 patients. Ann Oto Rhinol Laryn 1997;106(5):364-9. [CrossRef]

6. de Vincentiis M, Minni A, Gallo A, Di Nardo A. Supracricoid partial laryngectomies: oncologic and functional results. Head Neck 1998;20(6):504-9. [CrossRef]

7. Laccourreye $O$, Muscatello L, Laccourreye L, Naudo P, Brasnu D, Weinstein G. Supracricoid partial laryngectomy with cricohyoidoepiglottopexy for "early" glottic carcinoma classified as T1-T2N0 invading the anterior commissure. Am J Otolaryngol 1997;18(6):385-90. [CrossRef]

8. Page C, Mortuaire G, Mouawad F, Ganry O, Darras J, Pasquesoone $X$, et al. Supracricoid laryngectomy with cricohyoidoepiglottopexy (CHEP) in the management of laryngeal carcinoma: oncologic results. A 35-year experience. Eur Arch Otorhinolaryngol 2013;270(6):1927-32. [CrossRef]

9. Naudo P, Hans S, Laccourreye $O$, Laccourreye H, Weinstein $G$, Brasnu D. Functional outcome and prognosis factors after supracricoid partial laryngectomy with cricohyoidopexy. Ann Otol Rhinol Laryngol 1997;106(4):291-6. [CrossRef]

10. Bron L, Brossard E, Monnier P, Pasche P. Supracricoid partial laryngectomy with cricohyoidoepiglottopexy and cricohyoidopexy for glottic and supraglottic carcinomas. Laryngoscope 2000;110(4):627-34.[CrossRef] 